\title{
RISK FACTORS FOR RESPIRATORY DEATH AMONG INDONESIAN PILGRIMS IN 2018
}

\section{Faktor Risiko Kematian Akibat Penyakit Pernapasan Pada Jemaah Haji Indonesia Tahun 2018}

\author{
Prillia Syafira Liani ${ }^{1}$, Putri Bungsu Machmud ${ }^{2}$ \\ ${ }^{1}$ Department of Epidemiology, Faculty of Public Health, Universitas Indonesia, prilliasyafiraliani@gmail.com \\ ${ }^{2}$ Department of Epidemiology, Faculty of Public Health, Universitas Indonesia, putri.bungsu10@ui.ac.id \\ Corresponding Author: Putri Bungsu Machmud, putri.bungsu10@ui.ac.id, Department of Epidemiology, \\ Faculty of Public Health, University Indonesia, Pondok Cina, Beji, Depok, Indonesia, Postal Code 16424
}

\section{ARTICLE INFO \\ Article History: \\ Received October, $10^{\text {th }}, 2019$ \\ Revised form December, $28^{\text {th }}, 2019$ \\ Accepted January, 21th, 2020 \\ Published online January, 28 ${ }^{\text {th }}, 2020$}

\section{Keywords:}

respiratory disease;

death;

pilgrims;

risk factor

\section{Kata Kunci:}

penyakit pernapasan;

kematian;

jemaah haji;

faktor risiko

\begin{abstract}
Background: In 2018, respiratory disease was the leading cause of death in Hajj pilgrims, accounting for $37.40 \%$ of total deaths. Purpose: This study analyzes the most influential risk factors for death caused by respiratory disease among Indonesian pilgrims in 2018. Methods: This study uses a cross sectional design. Secondary data was obtained from the 2018 Integrated Hajj Computerized System for Health (Siskohatkes) and sourced from the Hajj Health Center (Puskeshaji), Ministry of Health of the Republic of Indonesia which is also recorded about the first to third Hajj medical examination records. The sample was all pilgrims who died while performing the Hajj in Saudi Arabia, 361 pilgrims. The variables included age, gender, pre-existing respiratory disease, education level, type of work, Body Mass Index (BMI), smoking status, and influenza vaccination status. The data was analyzed using chi square and multiple logistic regression. Results: The majority of pilgrims who died during the Hajj pilgrimage in Saudi Arabia in 2018 were aged $\geq 60$ years $(75.30 \%)$, male $(58.40 \%)$, did not have a pre-existing respiratory disease $(85.60 \%)$, had a low education level $(46.00 \%)$, worked indoors $(73.10 \%)$, had a normal BMI $(48.20 \%)$, did not smoke $(88.60 \%)$, and had had the influenza vaccine $(56.20 \%)$. The most influential risk factors were pre-existing respiratory disease with $\mathrm{PR}=1.55(95 \% \mathrm{CI}=1.16-2.90)$ and influenza vaccination status with $\mathrm{PR}=1.39(95 \% \mathrm{CI}=1.07-1.81)$. Conclusion: Having a preexisting respiratory disease and not being vaccinated against influenza increase the likelihood of respiratory disease death among Indonesian pilgrims in 2018.
\end{abstract}

(C2020 Jurnal Berkala Epidemiologi. Published by Universitas Airlangga. This is an open access article under CC-BY-SA license (https://creativecommons.org/licenses/by-sa/4.0/)

\section{ABSTRAK}

\begin{abstract}
Latar Belakang: Pada tahun 2018 kematian akibat penyakit pernapasan merupakan penyebab kematian pada jemaah haji tertinggi, yaitu sebesar $37,40 \%$ dari total kematian. Tujuan: Penelitian ini menganalisis faktor risiko yang paling berpengaruh terhadap kejadian kematian akibat penyakit pernapasan pada jemaah haji Indonesia tahun 2018. Metode: Penelitian ini menggunakan
\end{abstract}

\footnotetext{
How to Cite (APA): Liani, P. S., \& Machmud, P. B. (2020). Risk factors for respiratory death among Indonesian pilgrims in 2018. Jurnal Berkala Epidemiologi, 8(1), 57-64. https:/dx.doi.org/10.20473/ jbe.v8i12020.57-64
} haji Indonesia tahun 2018. Metode: Penelitian ini menggunakan 
desain studi cross sectional. Data sekunder didapatkan dari Sistem Komputerisasi Haji Terpadu Bidang Kesehatan (Siskohatkes) tahun 2018 yang bersumber dari Puskeshaji, Kementerian kesehatan Republik Indonesia yang didalamnya terdapat rekam medis pemeriksaan pertama sampai ketiga jemaah haji. Penelitian ini menggunakan total populasi, yaitu seluruh jemaah haji yang meninggal pada saat pelaksaanaan Ibadah Haji di Arab Saudi. Variabel yang diteliti adalah usia, jenis kelamin, pre-existing respiratory diseases, tingkat pendidikan, jenis pekerjaan, IMT, status merokok, dan vaksinasi influenza. Analisis menggunakan univariat, bivariat, dan multivariat dengan chi square dan regresi logistik ganda. Hasil: Mayoritas jemaah haji yang meninggal pada pelaksanaan ibadah haji di Arab Saudi tahun 2018 berada pada usia $\geq 60$ Tahun $(75,30 \%)$, berjenis kelamin laki-laki $(58,40 \%)$, tidak mempunyai status pre-existing respiratory diseases (85,60\%), memiliki tingkat pendidikan rendah (46,00\%), jenis pekerjaan indoor (73,10\%), IMT normal (48,20\%), tidak merokok (88,60\%), dan melakukan vaksinasi influenza (56,20\%). Faktor risiko yang paling berpengaruh dengan kematian akibat penyakit pernapasan pada jemaah haji Indonesia tahun 2018 adalah pre-existing respiratory diseases dengan $P R=1,55$ (95\% CI: 1,16-2,90) dan status vaksinasi influenza dengan $P R=1,39$ (95\%CI: 1,07-1,81). Kesimpulan: preexisting respiratory diseases dan status vaksinasi influenza merupakan faktor risiko yang paling berpengaruh terhadap kematian akibat penyakit pernapasan pada jemaah haji Indonesia tahun 2018.

C2020 Jurnal Berkala Epidemiologi. Penerbit Universitas Airlangga. Jurnal ini dapat diakses secara terbuka dan memiliki lisensi CC-BY-SA (https://creativecommons.org/licenses/by-sa/4.0/)

\section{INTRODUCTION}

The Hajj pilgrimage in Saudi Arabia is a once-in-a-lifetime obligation for all Muslims (Pane et al., 2019). In 2018 or $1439 \mathrm{H}$, the number of pilgrims from all over the world reached $2,371,675$, with 203,351 of these pilgrims traveling from Indonesia (Ministry of Health RI, 2018). Risk factors that exist in Saudi Arabia and within the pilgrims themselves can increase the likelihood of several diseases that have the potential to cause death. Deaths among pilgrims are proven by the existence of a Certificate of Death $(\mathrm{CoD})$, which is the main source of death or mortality data. The writing of the cause of death follows the rules set by the WHO in ICD-10 (Pane et al., 2019).

Data from the Indonesian Ministry of Health Hajj Health Center indicates that the number of pilgrims who died during the Hajj pilgrimage in Saudi Arabia has fluctuated over the past three years (2016-2018). In 2016, 341 pilgrims died, which increased to 658 in 2017, then decreased to 386 pilgrims in 2018. The leading cause of death for the last three years has been cardiovascular and respiratory disease (Ministry of Health RI, 2018). In 2016 and 2017, cardiovascular disease was the cause of death for $165(48.39 \%)$ and $176(26.74 \%)$ pilgrims, respectively, while respiratory disease was the cause of death for $88(25.80 \%)$ and 114 $(17.33 \%)$ pilgrims, respectively. This changed in 2018, with respiratory disease becoming the leading cause of death (142 pilgrims; 36.79\%) (Alfridaningrum, 2018).

Several risk factors contribute to the number of deaths due to respiratory disease during the Hajj pilgrimage, such as having a pre-existing respiratory disease and old age (Rudiyanto, 2013). For example, pilgrims aged $\geq 60$ years with or without disease and pilgrims aged $<60$ years with disease are included in the high-risk group according to the Indonesian Ministry of Health, and this is marked on their Pilgrim Health Card in orange (Ministry of Health RI, 2018). Another risk factors that also contribute to the health condition of pilgrims are behavioral risk factors, such as smoking, not having an influenza vaccination, high or low Body Mass Index (BMI), low physical activity, and high stress, socioeconomic risk factors, such as low levels of education and certain 
types of work and environmental risk factors specific to Saudi Arabia, such as the mass gathering of pilgrims causing the transmission of respiratory disease, temperatures reaching highs of $45^{\circ} \mathrm{C}$ and lows of $19^{\circ} \mathrm{C}$ with low humidity, and reduced access to health facilities and services (Rudiyanto, 2013). Previous studies have shown that age, education, and pre-existing respiratory disease are the factors most associated with the death of pilgrims (Rudini, 2016; Rudiyanto, 2013). This study analyzes the risk factors associated with death caused by respiratory disease in Indonesian pilgrims in 2018.

\section{METHODS}

This study used an analytic observational and cross-sectional study design. Secondary data was obtained from the Integrated Computerized Hajj System for Health (Siskohatkes) and included the medical records of the pilgrims' first, second, and third health examinations before they left for the Hajj pilgrimage. The data was sourced from the Hajj Health Center, Ministry of Health of the Republic of Indonesia in 2018.

Indonesian Hajj pilgrims who died during the pilgrimage in Saudi Arabia in 2018 were included in the study if their complete risk factor data was recorded in the Integrated Computerized Hajj System for Health. After 27 pilgrims with extreme data values had been excluded as outliers, the data of 361 remaining pilgrims was entered into the study.

The dependent variable in this study was the death of the Hajj pilgrims due to respiratory disease as stated in the CoD contained in the Siskohatkes data. The independent variables included the age of the pilgrims when they died according to their passports (categorized as <60 years and $\geq 60$ years) and whether or not they had a pre-existing respiratory disease, which was determined by the ICD-10 (J00-J99).

Risk factors related to the socioeconomic environment included level of education, which was categorized into higher education (diploma/Bachelor or higher degree), secondary education (high school/SMA), and primary education (junior high school/SMP, elementary school/SD, and no school). Type of employment, which was categorized as outdoor (e.g. farmer or military/police) or indoor (e.g. government civil servants/PNS, private sector, BUMN/BUMD employee, traders, housewives, and retirees).

Other risk factors analyzed in this study included smoking status and influenza vaccination status, which were based on the information in the pilgrims' first Hajj health examinations and were categorized as smoking/not smoking and vaccinated/not vaccinated, respectively. The pilgrims' BMI was also included in the analysis as this is a simple index used to determine if someone is under or overweight. A person's BMI is obtained by dividing their body weight in kilograms by the square of their height in meters $(\mathrm{kg} / \mathrm{m} 2)$. That person can then be categorized as being of normal weight (BMI 18.50-24.99), underweight (BMI <18.50), or overweight (BMI $\geq 25.00$ ).

\section{RESULTS}

Distribution of Cause of Death and Risk Factors of Death in Indonesian Hajj Pilgrims

There were 361 pilgrims who died during the implementation of the pilgrimage and respiratory diseases were the highest causes of death for pilgrims, amounting to 135 (37.40\%) (Table 1).

The majority of pilgrims who died during the Hajj pilgrimage in Saudi Arabia in 2018 were aged $\geq 60$ years $(75.30 \%)$, male $(58.40 \%)$, did not have a pre-existing respiratory disease $(85.60 \%)$, had a low education level $(46.00 \%)$, worked indoors (73.10\%), had a normal BMI $(48.20 \%)$, did not smoke $(88.60 \%)$, and had had the influenza vaccine $(56.20 \%)$ (Table 2).

\section{Relationship between Risk Factors and Death Caused by Respiratory Disease}

Bivariate test results showed that age, sex, education level, type of work, BMI, influenza vaccination status, and smoking status did not have a significant relationship with death caused by respiratory disease (ps > 0.05) (Table 3 ). In contrast, having a pre-existing respiratory disease was significantly associated with death due to respiratory disease $(\mathrm{p}=0.02)$, with pilgrims who had a pre-existing respiratory disease 1.49 times more likely to have died from respiratory disease compared to pilgrims who did not have a preexisting respiratory disease. The results also found that being underweight according to the BMI was significantly associated with death due to respiratory disease $(\mathrm{p}=0.03)$, with underweight pilgrims 1.44 times more likely to have died from respiratory disease compared to pilgrims with a normal BMI. Similarly, influenza vaccination status was also significantly related to death due to respiratory disease $(p=0.03)$, with pilgrims who had not had the influenza vaccination more likely to have died due to respiratory disease $(\mathrm{PR}=1.34)$ 
compared to pilgrims who had had the influenza vaccination (Table 3 ).

Table 1

Distribution of Diseases That Caused Death in Indonesian Hajj Pilgrims in 2018

\begin{tabular}{|c|c|c|}
\hline Cause of Death & $\mathrm{n}$ & $\%$ \\
\hline Respiratory Diseases & 135 & 37.40 \\
\hline Cardiovascular Diseases & 121 & 33.50 \\
\hline Infectious And Parasitic Disease & 23 & 6.40 \\
\hline Malignant Neoplasms (cancers) & 6 & 1.70 \\
\hline Digestive Diseases & 12 & 3.30 \\
\hline $\begin{array}{l}\text { Diseases of the genitourinary } \\
\text { system }\end{array}$ & 7 & 1.90 \\
\hline Circulatory Diseases & 36 & 10.00 \\
\hline $\begin{array}{l}\text { Endocrine, nutritional and } \\
\text { metabolic diseases }\end{array}$ & 17 & 4.70 \\
\hline $\begin{array}{l}\text { Injury, poisoning and certain } \\
\text { other consequences of external }\end{array}$ & 4 & 1.10 \\
\hline Total & 361 & 100.00 \\
\hline
\end{tabular}

\section{Most Influential Risk Factors}

The PR-adjusted model showed that the most influential risk factor was pre-existing respiratory disease $(\mathrm{PR}=1.55 ; 95 \% \mathrm{CI}: 1.16-2.90)$, with pilgrims who had a pre-existing respiratory disease 1.55 times more likely to have died from respiratory disease compared to pilgrims who did not have a pre-existing respiratory disease. Influenza vaccination status was the second most influential risk factor $(\mathrm{PR}=1.39$; 95\% CI: $1.07-$ 1.81 ), with pilgrims who had not had the influenza vaccination 1.39 times more likely to have died from respiratory disease compared to pilgrims who had had the influenza vaccination (Table 4).

\section{DISCUSSION}

\section{Distribution of Diseases That Cause Death in Indonesian Hajj Pilgrims}

The results found that the highest cause of death during Hajj pilgrimage in 2018 were due to respiratory diseases amounted 135 (37.40\%) pilgrims died and the rest were other diseases amounted 226 (62.60\%). In the last three years, respiratory disease is the third largest cause of death in Indonesian pilgrims, in $2016=88$ $(25.80 \%)$ and in $2017=114(17.33 \%)$ of the total pilgrims who died in that year (Alfridaningrum, 2018).
Table 2

Distribution of Death Risk Factors in Hajj Pilgrims in 2018

\begin{tabular}{lrc}
\hline \multicolumn{1}{c}{ Risk Factor } & $\mathrm{n}$ & $\%$ \\
\hline Age (years old) & & \\
$\geq 60$ & 272 & 75.30 \\
$\quad<60$ & 89 & 24.70 \\
Sex & & \\
$\quad$ Male & 211 & 58.40 \\
$\quad$ Female & 150 & 41.60 \\
Pre-Existing Respiratory & & \\
Disease (RD) Status & & \\
$\quad$ Pre-Existing RD & 52 & 14.40 \\
$\quad$ No Pre-Existing RD & 309 & 85.60 \\
Education & & \\
$\quad$ Higher & 135 & 37.40 \\
Secondary & 60 & 16.60 \\
$\quad$ Primary & 166 & 46.00 \\
Type of Work & & \\
$\quad$ Outdoor & 97 & 26.90 \\
$\quad$ Indoor & 264 & 73.10 \\
BMI & & \\
$\quad$ Normal & 174 & 48.20 \\
$\quad$ Underweight & 67 & 18.60 \\
Overweight & 120 & 33.20 \\
Smoking Status & & \\
$\quad$ Smoking & 41 & 11.40 \\
$\quad$ Not Smoking & 320 & 88.60 \\
Influenza & & \\
Status & & \\
$\quad$ Vaccinated & & \\
$\quad$ Not Vaccinated & 203 & 56.20 \\
\hline Total & 158 & 43.80 \\
\hline$\quad$ & 361 & 100.00 \\
\hline
\end{tabular}

\section{Relationship between Genetic Risk Factors and Death Caused by Respiratory Disease}

The results of this study stated that there is no correlation between age and death in Indonesian pilgrims. It differ from other studies, there is a relationship between age and death in Indonesian pilgrims (Rudini, 2016; Rudiyanto, 2013). This difference could be due to the different population and analysis techniques. Rudiyanto (2013) found that the higher the age of the pilgrims, the higher their risk of death. That study also found that pilgrims aged over 60 years were more at risk of death caused by respiratory disease compared to those aged under 60 years. As we get older, the respiratory system undergoes various anatomic, physiological, and immunological changes. Other factors such as new environmental conditions and new activities can make it difficult for elderly pilgrims to adapt, and mass gatherings of pilgrims from all over the world can potentially lead to the 
transmission of meningitis, H1N1, Mers-CoV, influenza, etc (Gautret, Benkouiten, Al-Tawfiq, \& Memish, 2016; Khan \& Khan, 2018). Elderly pilgrims can be more vulnerable to contracting diseases, especially influenza (Hashem et al., 2019).

The results indicated that sex is not a risk factor for death in Indonesian pilgrims, which is in line with Rudini (2016) findings. In contrast, a study conducted in Russia looking at death caused by respiratory disease found that men were twice as likely to die from respiratory disease compared to women (Manakov, Kolosov, Polyanskaya, \& Naryshkina, 2017). This difference could be due to the due to differences in activities in Saudi Arabia, differences in unhealthy living habits before leaving for Hajj (such as smoking), and the different levels of awareness of treatment between male and female (Rudiyanto, 2013).

The results showing a relationship between having a pre-existing respiratory disease and death in Indonesian pilgrims are in line with other studies (Pane et al., 2019; Rudini, 2016). The available data also indicated that the most common respiratory diseases found in pilgrims were COPD (chronic obstructive pulmonary disease), asthma, and pneumonia. Hajj requires a large amount of physical activity, and someone who has a respiratory disease or other illness will already be in poor health. There are also several risk factors associated with Hajj in Saudi Arabia that can contribute to the severity of respiratory disease, such as a lack of rest and dehydration. Pilgrims with pre-existing respiratory diseases like asthma or COPD may experience asthma attacks or difficulty breathing, which if not dealt with immediately can cause respiratory failure and death (Ihaji, Gerald, Helen, \& Ogwuche, 2014; Pane et al., 2019; Rahman, Thu, Arshad, \& Van der Putten, 2017; Rudini, 2016).

Table 3

Relationship between Risk Factors and Death Caused by Respiratory Disease (RD) in Indonesian Pilgrims

\begin{tabular}{|c|c|c|c|c|c|c|c|c|}
\hline \multirow{3}{*}{ Risk Factor } & \multicolumn{4}{|c|}{ Death Caused by RD } & \multirow{3}{*}{ Total } & \multirow{3}{*}{ PR } & \multirow{3}{*}{$95 \% \mathrm{CI}$} & \multirow{3}{*}{$p$} \\
\hline & \multicolumn{2}{|c|}{ RD } & \multicolumn{2}{|c|}{ Non RD } & & & & \\
\hline & $\mathrm{n}$ & $\%$ & $\mathrm{n}$ & $\%$ & & & & \\
\hline \multicolumn{9}{|l|}{ Age (years old) } \\
\hline$\geq 60$ & 102 & 37.50 & 170 & 62.50 & 272 & 1.01 & $(0.74-1.38)$ & 0.94 \\
\hline$<60$ & 33 & 37.10 & 56 & 62.90 & 89 & & & \\
\hline \multicolumn{9}{|l|}{ Sex } \\
\hline Male & 79 & 37.40 & 132 & 62.60 & 211 & 1.00 & $(0.76-1.31)$ & 0.98 \\
\hline Female & 56 & 37.30 & 94 & 62.70 & 150 & & & \\
\hline \multicolumn{9}{|l|}{ Pre-existing $R D$} \\
\hline Have & 27 & 51.90 & 25 & 48.10 & 52 & 1.49 & $(1.09-2.01)$ & 0.02 \\
\hline Not Have & 108 & 35.00 & 201 & 65.00 & 309 & & & \\
\hline \multicolumn{9}{|l|}{ Education } \\
\hline Primary & 60 & 36.10 & 106 & 63.90 & 166 & 0.96 & $(0.71-1.29)$ & 0.77 \\
\hline Secondary & 24 & 40.00 & 36 & 60.00 & 60 & 1.06 & $(0.72-1.54)$ & 0.77 \\
\hline Higher & 51 & 37.80 & 84 & 62.20 & 135 & & & \\
\hline \multicolumn{9}{|l|}{ Type of work } \\
\hline Indoor & 91 & 34.50 & 173 & 65.50 & 264 & 0.76 & $(0.58-0.10)$ & 0.06 \\
\hline Outdoor & 44 & 45.40 & 53 & 54.60 & 97 & & & \\
\hline \multicolumn{9}{|l|}{ BMI } \\
\hline Underweight & 31 & 46.30 & 36 & 53.70 & 67 & 1.44 & $(1.03-2.01)$ & 0.03 \\
\hline Overweight & 48 & 40.00 & 72 & 60.00 & 120 & 1.24 & $(0.91-1.69)$ & 0.17 \\
\hline Normal & 56 & 32.20 & 118 & 67.80 & 174 & & & \\
\hline \multicolumn{9}{|l|}{ Smoking Status } \\
\hline Smoking & 17 & 41.50 & 24 & 58.50 & 41 & 1.21 & $(0.76-1.66)$ & 0.57 \\
\hline Not Smoking & 118 & 36.90 & 202 & 63.10 & 320 & & & \\
\hline \multicolumn{9}{|c|}{ Influenza Vaccination Status } \\
\hline Not Vaccinated & 69 & 43.70 & 89 & 56.30 & 158 & & & 003 \\
\hline Vaccinated & 66 & 32.50 & 137 & 67.50 & 203 & 1.34 & $(1.03-1 . / 5)$ & 0.03 \\
\hline Total & 135 & 100.00 & 226 & 100.00 & 361 & & & \\
\hline
\end{tabular}


Table 4

Final Model of Multivariate Analysis

\begin{tabular}{|c|c|c|}
\hline Variable & $\begin{array}{c}\mathrm{PR} \\
(95 \% \mathrm{CI})\end{array}$ & $p$ \\
\hline Pre-existing $R D$ & $\begin{array}{r}1.55 \\
(1.16-2.90)\end{array}$ & 0.00 \\
\hline $\begin{array}{l}\text { Influenza Vaccination } \\
\text { Status }\end{array}$ & $\begin{array}{r}1.39 \\
(1.07-1.81)\end{array}$ & 0.01 \\
\hline
\end{tabular}

\section{Relationship between Socioeconomic Risk Factors and Death Caused by Respiratory Disease}

The results of this study state that there is no correlation between education level and death in Indonesian pilgrims. It contrast with the findings of Rudini (2016) study which showed that there is a significant correlation between education level and death in Indonesia pilgrims. This difference could be caused by different samples or populations and analysis techniques. Level of education can signify knowledge and health seeking behavior. For example, Ihaji, Gerald, Helen, \& Ogwuche (2014) found that someone with a higher level of education had a greater level of awareness when it came to seeking treatment compared to people with a lower level of education.

The results of this study showed that there is no correlation between type of work and death in Indonesian pilgrims. It's in line with other studies. For example, Medistianto (2017) found that type of work was not related because the categorization is less sensitive and the type of pilgrimage work is indeed difficult to say can be directly related to deaths of Indonesian pilgrims that caused by respiratory diseases, even though in that study found the results that the indoor work category is a protective factor. This could be due to the number of pilgrims who were farmers included in the outdoor category as is the largest type of work of Indonesian pilgrims that has died because of respiratory disease, which is $45.70 \%$ of each type of work. Farmers also had the highest proportion of pre-existing respiratory disease compared to the other occupations, and it has been found that preexisting respiratory disease is a risk factor for death due to respiratory disease. The farmers who died from respiratory disease also had the highest proportion of smokers compared to the other types of work, and smoking can cause respiratory disease, especially Chronic Obstructive Pulmonary Disease (COPD) (Riesco et al., 2017)

\section{Relationship between Behavior Risk Factors and Death Caused by Respiratory Disease}

The results showed that BMI was not associated with death caused by respiratory disease. Other studies have found that underweight adults have higher rates of respiratory death than adults who are a normal weight, but it is unclear whether this association is causal or reflects illness-induced weight loss (reverse causality) (Kivimäki et al., 2016). The results of other studies have shown that severe COPD is significantly associated with being underweight Eriksson et al (2016), while being overweight or obese is associated with cardiovascular disease or death caused by cardiovascular disease (Gregory et al., 2017; Khan et al., 2018).

The results also showed that smoking was not related to death caused by respiratory disease, which is in contrast with another studies. Smoking can make respiratory disease worse rather than directly causing death (West, 2017). It can also negatively affect the immune system and damage lung tissue, causing respiratory disease and increasing the risk of respiratory infections (Zuo et al., 2014). Smoking also increases the risk of pneumonia and chronic bronchitis (Restrepo, Sibila, \& Anzueto, 2018). This difference could be due to the the proportion of pilgrims who smoked less $(11.40 \%)$ than those who did not smoke. This can be caused at the time of the health examination, only smoking behavior was asked, not a history of smoking.

The results showed that influenza vaccination status was associated with death caused by respiratory disease. Respiratory infections are very common and easily transmitted during Hajj, therefore, the influenza vaccination plays an important role in preventing people from catching these infections (Benkouiten, Al-Tawfiq, Memish, Albarrak, \& Gautret, 2019; Khan et al., 2018). In a previous study, it was found that pilgrims who had had the influenza vaccination were less likely to have acute respiratory infections, especially influenza-like illnesses (Alfelali et al., 2018). According to other studies, the influenza vaccination is considered effective at reducing respiratory disease infections in pilgrims (Zeitouni et al., 2015). In a systematic review conducted in China, it was found that the influenza vaccination was associated with a significant reduction in mortality due to COPD and pneumonia and that it could also reduce acute exacerbation of COPD (Bekkat-Berkani et al., 2017).

There is a significant relationship between vaccination status and death due to respiratory 
disease in pilgrims, but this needs to be further understood. The influenza vaccination can directly reduce complications associated with and the exacerbation of COPD, which can help prevent death from respiratory failure, and also directly reduce the transmission of respiratory infections (Alfelali et al., 2018).

\section{Research Limitation}

This study used a cross-sectional design, therefore, a causal relationship cannot be identified. Variables such as age, sex, level of education, type of work, BMI, and smoking status are indirect causes of death due to respiratory disease, and the data only included whether the pilgrims smoked at the time of their first health examination rather than providing a smoking history. Not all of the data was used as 27 outliers were excluded.

\section{CONCLUSION}

The most influential risk factors for death due to respiratory disease in pilgrims are pre-existing respiratory disease and influenza vaccination. The risk factors of age, sex, level of education, type of work, BMI, and smoking status were found to be unrelated to death caused by respiratory disease in the Indonesian pilgrims in 2018. Pilgrims should make sure they have the influenza vaccination before leaving for Saudi Arabia, especially those with a pre-existing respiratory disease like COPD, asthma, or pneumonia. Although there is a small possibility of respiratory disease transmission after having the vaccination, it still reduces the symptoms of respiratory disease.

\section{CONFLICT OF INTEREST}

The authors declare that no conflict of interest in this study.

\section{ACKNOWLEDGMENT}

Thanks to the Hajj Health Center, Ministry of Health of the Republic of Indonesia for the research data.

\section{REFERENCES}

Alfelali, M., Barasheed, O., Badahdah, A. M., Bokhary, H., Azeem, M. I., Habeebullah, T., ... Rashid, H. (2018). Influenza vaccination among Saudi Hajj pilgrims: Revealing the uptake and vaccination barriers. Vaccine,
36(16),

2112-2118.

https://doi.org/10.1016/j.vaccine.2018.03.007

Alfridaningrum. (2018). Gambaran tren kematian jemaah haji reguler Indonesia kelompok umur lansia tahun 2015, 2016, dan 2017 (analisis data siskohatkes pusat kesehatan haji Kemeterian Kesehatan RI). Undergraduated Thesis. Faculty of Public Health. Universitas Indonesia.

Bekkat-Berkani, R., Wilkinson, T., Buchy, P., Dos Santos, G., Stefanidis, D., Devaster, J. M., \& Meyer, N. (2017). Seasonal influenza vaccination in patients with COPD: A systematic literature review. $B M C$ Pulmonary Medicine, 17(1), 1-15. https://doi.org/10.1186/s12890-017-0420-8

Benkouiten, S., Al-Tawfiq, J. A., Memish, Z. A., Albarrak, A., \& Gautret, P. (2019). Clinical respiratory infections and pneumonia during the Hajj pilgrimage: a systematic review. Travel Medicine and Infectious Disease, 28, 15-26. https://doi.org/10.1016/j.tmaid.2018.12.002

Eriksson, B., Backman, H., Bossios, A., Bjerg, A., Hedman, L., Lindberg, A., ... Lundbäck, B. (2016). Only severe COPD is associated with being underweight: Results from a population survey. ERJ Open Research, 2(3), $1-11$.

Gautret, P., Benkouiten, S., Al-Tawfiq, J. A., \& Memish, Z. A. (2016). The spectrum of respiratory pathogens among returning hajj pilgrims: myths and reality. International Journal of Infectious Diseases, 47, 83-85. https://doi.org/10.1016/j.ijid.2016.01.013

Gregory, A. B., Lester, K. K., Gregory, D. M., Twells, L. K., Midodzi, W. K., \& Pearce, N. J. (2017). The relationship between body mass index and the severity of coronary artery disease in patients referred for coronary angiography. Cardiology Research and Practice, 2017(5481671), 1-10. https://doi.org/10.1155/2017/5481671

Hashem, A. M., Al-Subhi, T. L., Badroon, N. A., Hassan, A. M., Bajrai, L. H. M., Banassir, T. M., ... Azhar, E. I. (2019). MERS-CoV, influenza and other respiratory viruses among symptomatic pilgrims during 2014 hajj season. Journal of Medical Virology, 91(6), 911-917. https://doi.org/10.1002/jmv.25424

Ihaji, E., Gerald, E. U., Helen, C., \& Ogwuche, E. (2014). Educational level, sex and church affiliation on health seeking behaviour among parishioners in Makurdi Metropolis of 
Benue State. Journal of Educational Policy and Entrepreneurial Research (JEPER), 1(2), 311-316.

Khan, I. D., Khan, S. A., Asima, B., Hussaini, S. B., Zakiuddin, M., \& Faisal, F. A. (2018). Morbidity and mortality amongst Indian hajj pilgrims: a 3-year experience of Indian hajj medical mission in mass-gathering medicine. Journal of Infection and Public Health, 11(2), 165-170. https://doi.org/10.1016/j.jiph.2017.06.004

Khan, S., \& Khan, I. D. (2018). Obstetric and neonatal outcomes of pregnant Indian pilgrims: a three-year experience at the Indian Hajj medical mission. Sultan Qaboos University Medical Journal, 18(3), 355-361. https://doi.org/10.18295/squmj.2018.18.03.0 15

Khan, S. S., Ning, H., Wilkins, J. T., Allen, N., Carnethon, M., Berry, J. D., ... Lloyd-Jones, D. M. (2018). Association of body mass index with lifetime risk of cardiovascular disease and compression of morbidity. JAMA Cardiology, 3(4), 280-287. https://doi.org/10.1001/jamacardio.2018.002 2

Kivimäki, M., Shipley, M. J., Bell, J. A., Brunner, E. J., Batty, G. D., \& Singh-Manoux, A. (2016). Underweight as a risk factor for respiratory death in the Whitehall cohort study: exploring reverse causality using a $45-$ year follow-up. Thorax, 71(1), 84-85. https://doi.org/10.1136/thoraxjnl-2015207449

Manakov, L. G., Kolosov, V. P., Polyanskaya, E. V, \& Naryshkina, S. V. (2017). Gender and age gradients of the population rate of death caused by respiratory diseases on the territory of the far-eastern region of Russia. Official Journal of the Asian Pacific Society of Respirology, 22(3), 259.

Medistianto, E. (2017). Hubungan riwayat hipertensi sebelum melaksanakan ibadah haji dengan kematian jemaah haji Indonesia asal Provinsi Jambi saat melaksanakan ibadah haji pada pelaksanaan ibadah haji tahun 2017. Undergraduated Thesis. Faculty of Public Health. Universitas Indonesia.

Ministry of Health RI. (2018). Indonesia hajj health services. Ministry of Health RI. Jakarta.

Pane, M., Kong, F. Y. M., Purnama, T. B., Glass, K., Imari, S., Samaan, G., \& Oshitani, H. (2019). Indonesian hajj cohorts and mortality in Saudi Arabia from 2004 to 2011. Journal of Epidemiology and Global Health, 9(1), $11-18$. https://doi.org/10.2991/jegh.k.181231.001

Rahman, J., Thu, M., Arshad, N., \& Van der Putten, M. (2017). Mass gatherings and public health: case studies from the hajj to Mecca. Annals of Global Health, 83(2), 386393.

https://doi.org/10.1016/j.aogh.2016.12.001

Restrepo, M. I., Sibila, O., \& Anzueto, A. (2018). Pneumonia in patients with chronic obstructive pulmonary disease. Tuberculosis and Respiratory Diseases, 81, 187-197. https://doi.org/10.4046/trd.2018.0030

Riesco, J. A., Alcázar, B., Trigueros, J. A., Campuzano, A., Pérez, J., \& Lorenzo, J. L. (2017). Active smoking and COPD phenotype: distribution and impact on prognostic factors. International Journal of COPD, 12, 1989-1999. https://doi.org/10.2147/COPD.S135344

Rudini. (2016). Faktor-faktor yang berhubungan dengan kejadian kematian jamaah haji reguler Indonesia tahun $2015 \mathrm{M} / 1436 \mathrm{H}$. Undergraduated Thesis. Faculty of Public Health. Universitas Indonesia.

Rudiyanto. (2013). Riwayat penyakit terdiagnosis pada pemeriksaan kesehatan di embarkasi dan kematian jemaah haji Indonesia tahun 2012 M (evaluasi pencatatan pelaporan sistem informasi manajemen kesehatan haji) (Universitas Indonesia). Undergraduated Thesis. Faculty of Public Health. Universitas Indonesia.

West, R. (2017). Tobacco smoking: health impact, prevalence, correlates and interventions. Psychology and Health, 32(8), 1018-1036. https://doi.org/10.1080/08870446.2017.1325 890

Zeitouni, M. O., Al Barrak, A. M., Al-Moamary, M. S., Alharbi, N. S., Idrees, M. M., Al Shimemeri, A. A., \& Al-Hajjaj, M. S. (2015). The Saudi Thoracic Society guidelines for influenza vaccinations. Annals of Thoracic Medicine, 10(4), 223-230. https://doi.org/10.4103/1817-1737.167065

Zuo, L., He, F., Sergakis, G. G., Koozehchian, M. S., Stimpfl, J. N., Rong, Y., ... Best, T. M. (2014). Interrelated role of cigarette smoking, oxidative stress, and immune response in COPD and corresponding treatments. American Journal of Physiology - Lung Cellular and Molecular Physiology, 307(3), 205-218. 